\title{
\#PARTICIPE: A INTERATIVIDADE DO FAZER TELEVISUAL
}

\author{
FERNANDA SAGRILO ANDRES \\ UNIVERSIDADE FEDERAL DO PAMPA \\ SÃO BORJA, RIO GRANDE DO SUL, BRASIL \\ FERSAGRILO@GMAIL.COM \\ MARIA LÍLIA DIAS DE CASTRO \\ UNIVERSIDADE FEDERAL DE SANTA MARIA \\ SANTA MARIA, RIO GRANDE DO SUL, BRASIL \\ MLILIA@TERRA.COM.BR
}

HTTP://DX.DOI.ORG/10.5902/2316882X29488 


\section{\#PARTICIPE: A INTERATIVIDADE DO FAZER TELEVISUAL}

Resumo: Este estudo, tomando como ponto de partida o papel da televisão frente a nova realidade oferecida por outros dispositivos e plataformas, busca investigar o fenômeno da interatividade, entre emissora e público, que contamina o fazer televisual no país, a partir das três temporadas dos programas SuperStar e MasterChef.

Palavras-chave: estratégia; interatividade; mídia televisual; prática interativa; texto de segunda tela.

\section{\#PARTICIPATE: THE INTERACTIVITY OF THE TELEVISUAL}

Abstract: Taking as the start point the role of TV in face of this new reality established for other devices and platforms, this study seeks to investigate the phenomenon of interactivity between broadcaster and public that contaminates the audiovisual production in Brazil, focusing on the three seasons of the program Master Chef and the program Superstar.

Keywords: strategy; Interactivity; TV media; Interactive practice; Second screen text.

\section{\#PARTICIPE: LA INTERACTIVIDAD DEL HACER TELEVISUAL}

Resumen: El estudio, tomando como punto de partida el papel de la televisión frente a la nueva realidad ofrecida por otros dispositivos y plataformas, busca investigar el fenómeno de la interactividad, entre emisora y público, que contamina el hacer televisión en el país, a partir de las tres temporadas de los programas SuperStar y MasterChef.

Palabras clave: estrategia; interactividad; medios de comunicación; práctica interactiva; texto de segunda pantalla. 


\section{INTRODUÇÃO, OBJETIVOS, CONSIDERAÇÕES METODOLÓGICAS}

O advento da web 2.0, das redes e das mídias sociais vem acarretando uma constante retroalimentação entre a televisão e as tecnologias digitais, ampliando os limites das narrativas, tornando híbridos os espaços de produção, circulação e recepção de mensagens e, ainda, motivando os telespectadores/usuários a se engajar nas produções televisuais. Aliás, essas novas possibilidades tecnológicas na área da comunicação redundam em processos interativos entre instituições, mídias e públicos, que se afetam constante e mutuamente.

Nessa perspectiva, entendendo a televisão como esse objeto complexo e rico, e passível de ser visualizado sob diferentes ângulos, este trabalho toma como ponto de partida o papel da televisão frente às outras mídias e plataformas, o que, de certa forma, reconfigura a maneira de consumo dos produtos midiáticos. O telespectador divide sua atenção entre o conteúdo exibido na tela do televisor e o uso de telas de smartphone, tablet, laptop ou qualquer outro aparelho com acesso à internet. Quem assiste à televisão com esses recursos tecnológicos está descobrindo novas opções de integração entre telas.

O objetivo de todas essas inovações, pela televisão, é conseguir maior oferecimento de conteúdo em tempo real, conexão mais efetiva com o telespectador, interferência das mídias digitais na programação televisual, trazendo, acima de tudo, em especial nas televisões comerciais, fortalecimento e expansão da marca da emissora. E isso tudo porque, a qualquer momento, ela pode remeter o telespectador a outras plataformas ou convocá-lo a lançar sua opinião sobre a programação em curso.

Isso gera um segundo movimento: o envio de mensagens desses aparelhos com opiniões sobre a programação, e essas informações são sobrepostas na tela da televisão, através dos ambientes digitais como as redes sociais, sites e/ou aplicativos. Esse depoimento ao vivo, retratado na tela, funciona como testemunho do telespectador/usuário do que está sendo exibido.

Nesse contexto, de valorização do uso constante de smartphones, tablets e computadores, pelos usuários, e da preocupação das emissoras com as práticas interativas dentro dos programas na grade, o objeto de estudo são os programas do subgênero talent show: SuperStar, da TV Globo, e MasterChef, da TV Bandeirantes.

Rev.Cad.Comun. Santa Maria, v.21, n.3, art 9, p. 169 de 175, set/dez.2017 
SuperStar é um talent show musical, no qual bandas se enfrentam, e as manifestações sobre os concorrentes, enviadas pelos telespectadores/ usuários, são sobrepostas à tela. De formato israelense, o talent tem como principal atrativo o fato de o público votar em tempo real, por meio de um aplicativo para smartphones, tablets e computadores. Já MasterChef é um talent show de culinária, baseado no consagrado formato original de mesmo nome, exibido pela BBC no Reino Unido, que busca transformar um cozinheiro amador em um chef profissional. Ainda que não deposite no telespectador a responsabilidade pela escolha do vencedor, emprega as redes sociais digitais, em especial o Twitter, como parceiros na produção televisiva, fazendo com que seja um dos programas mais comentados na ambiência digital.

Convém ressaltar que, nesse processo de utilização da tela dupla, a televisão funciona como tela principal, enquanto as informações oriundas das redes sociais digitais têm a função de reverberar o produto televisivo, acarretando a aparente simultaneidade dos processos de criação, circulação e consumo de conteúdo. Os recursos disponíveis na integração de telas complementam a experiência do telespectador/usuário, além de oferecerem informações que enriquecem o que está sendo mostrado e, eventualmente, possam modificar a sequência de exibição do programa.

Sabe-se que os processos comunicacionais não são inocentes: há sempre intencionalidades, convocação de públicos e movimentos para obter êxito. Nessa direção, estrategicamente, os produtos midiáticos televisuais estão investindo na possibilidade da participação de sujeitos no processo de produção dos programas, o que se torna possível com o uso simultâneo de dois recursos pelo telespectador: o aparelho de televisão e outros que dispõem de acesso à internet. Essa ação torna-se uma boa estratégia de interpelação, na medida em que convoca os telespectadores/usuários ao compartilhamento e à participação no processo televisual. Tudo isso parece reverter em benefício da emissora, uma vez que possibilita o permanente investimento em avanços tecnológicos, criando um espaço de diálogo entre os públicos de interesse, conferindo visibilidade e legitimidade à empresa.

Diante do exposto, o objetivo desta pesquisa é examinar, em tempos de convergência midiática, o elenco das práticas encabeçadas pelas emissoras, na tentativa de criar interatividade com o telespectador/usuário, para verificar repercussões e implicações na produção televisual. Buscan-

Rev.Cad.Comun. Santa Maria, v.21, n.3, art 9, p. 170 de 175, set/dez.2017 
do contemplar o objetivo proposto, este trabalho tem, como pano de fundo, o exame da interface televisão, público e mídia digital; a convocação do aporte teórico-metodológico da semiótica greimasiana; e a reflexão sobre o papel dos avanços tecnológicos nas produções televisuais.

O foco do trabalho não está propriamente na tecnologia empregada, mas, sim, no tipo de conteúdo compartilhado, nas experiências efetivadas pelo público, nas ações realizadas pelos telespectadores/usuários e nos convites feitos pelos programas/emissoras para conquistar a audiência e garantir o ineditismo e a valorização da ação televisual. Até porque, "mais do que a existência de possibilidades tecnológicas, são os hábitos culturais e sociais de consumo que determinam o caminho a ser percorrido pela TV" (CANNITO, p.135, 2010).

\section{PRINCIPAIS RESULTADOS E CONCLUSÕES}

Se antes as emissoras temiam a concorrência com outra tela, pelo temor de dispersar a audiência para outras mídias, elas hoje se empenham em buscar estratégias que as integrem e que incentivem a ação dupla. SuperStar e MasterChef exemplificam o novo modelo televisivo, que deixa de estar vinculada exclusivamente ao conteúdo exibido no aparelho de TV e se amplia para uma experiência marcada pelo hibridismo com outros meios, embora, na tela da TV, tudo ainda seja controlado pela própria emissora, como as escolhas dos tuites, das imagens e fotos a serem exibidos no monitor, com aquele "efeito de interatividade". Até porque, por enquanto, a ação efetiva de interatividade fica restrita às redes sociais.

Todos esses movimentos estratégicos feitos pelas emissoras refletem, nos textos de segunda tela gerados pelas práticas interativas, questões relativas à: qualificação da emissora responsável pela emissão; enaltecimento das possibilidades de inovação tecnológica do programa; confirmação da aceitação do programa por celebridade; valorização dos competidores (bandas ou cozinheiros); satisfação do telespectador/usuário por aparecer na tela, através da sala da interatividade, das fotos divulgadas e dos comentários filtrados; tradução do efeito sensitivo do telespectador; reiteração do testemunho do telespectador; consolidação da aceitação do programa (reforço da audiência).

$\mathrm{Na}$ verdade, todas essas ações provocam diferentes efeitos no telespectador/usuário. Ao disponibilizar certas possibilidades e ofertar recur-

Rev.Cad.Comun. Santa Maria, v.21, n.3, art 9, p. 171 de 175, set/dez.2017 
sos na tela, a emissora acaba gerando efeitos de sentido de diferentes ordens, a saber, temporalidade - de agora, de ao vivo, de instantaneidade, de assistir junto, de estar compartilhando a mesma experiência com outras pessoas, no mesmo momento; espacialidade - de presença, de estar junto; interatividade - de encontro, de experiência, de trocas de mensagens, de fazer parte, de participar da produção televisual, de diálogo com outro (produtor e receptor); e de visibilidade - de estar na tela, de aparecer na televisão, de ser visto.

Parece que a ideia dar espaço para a audiência participar do programa, ainda que seja nos 140 caracteres do Twitter, respondendo a enquete ou expondo sua opinião, fotografia ou criação na tela, dá a chance de fidelizar o público, fazendo com que aquilo se torne uma ação dupla: de divulgação do produto televisual e de valorização ao telespectador/usuário.

Assim, a audiência televisiva acaba sendo impulsionada pelos tuites, já que comentários publicados na rede social podem levar usuários a se tornarem telespectadores e acompanhar um programa de TV e, do mesmo modo, quando um programa gera audiência significativa na TV, a quantidade de postagens na rede social aumenta consideravelmente. Ou seja, o fenômeno segunda tela é forte aliado na expansão dos conteúdos televisivos, já que oferece aos telespectadores/usuários uma melhor experiência, colabora na fidelização da audiência e facilita a disseminação das atrações através dos compartilhamentos nos sites de redes sociais.

Desse modo, com os dois universos se retroalimentando mutuamente, TV e internet, os programas projetam uma espécie de gramática da interatividade, do ato interativo, que compreende esse conjunto de níveis, que, envolvendo o ato individual, concorrem para a ação de interagir. Deve-se, contudo, ressaltar que, por mais que o programa viabilize a participação individual de cada telespectador/usuário, a escolha definitiva do texto a ser exibido é determinada pelas emissoras.

Essas ações podem ser vistas como uma tentativa potencial de dialogar com os públicos não habituais da TV, público que estava nas redes sociais e que se sentiu atraído pelos desafios lançados pela emissora. Toda essa compreensão leva à reflexão daquilo que Castro (2004) reconhece como movimento macro de divulgação, ao afirmar que a mídia televisual, ao lado das importantes funções desempenhadas - entreter, educar e informar -, traz ainda uma outra que, verdadeiramente, perpassa as demais: a de promover. Derivado do latim promovere, o termo significa engran- 
decer, divulgar, explicitar, impelir à frente; o seu uso refere-se à divulgação (ação de propagar qualquer produto, marca, valor, serviço ou pessoa para o estabelecimento de relações de troca) e/ou projeção (lançar algo à frente tornando conhecido e respeitado), de produtos, ideias, serviços, marcas e valores.

Nesse sentido, a função promocional, além de divulgar e tornar público, também projeta e confere prestígio a tudo que é veiculado na tela, seja a programação em seu todo, o serviço prestado, a pessoa representada. Pensando em todas as funções da televisão, entende-se que a de promover, além de satisfazer o receptor, como as demais, também favorece o sujeito da produção. Basta estar na tela para adquirir prestígio, talvez, por isso, o entendimento de promoção seja tão amplo,

Vai além do simples interesse de venda, pois envolve tudo aquilo que a televisão representa para o cidadão comum: desde apresentação da grade, divulgação de produtos, ações de interesse da comunidade, até movimentos que redundem em benefício às pessoas e à empresa (CASTRO, 2010, p.2).

Sendo assim, a promocionalidade ganha um âmbito bastante abrangente, que vai além da peça publicitária, limitada ao espaço e tempo de duração, atingindo instâncias diversas, de ordem econômica, mercadológica, social e comercial. Constitui, assim, um verdadeiro gênero, que engloba uma variada gama de textos, cuja função é divulgar, tornar público e/ou conferir prestígio a produtos, pessoas, marcas, serviços, ideias. 
CADERNOS DE COMUNICAÇÃO

UNIVERSIDADE FEDERAL DE SANTA MARIA

\section{REFERÊNCIAS}

CANNITO, Newton. A televisão na era digital: interatividade, convergência e novos modelos de negócio. São Paulo: Summus, 2010.

CASTRO, M.L.D. Autopromocionalidade televisual: lógicas e configurações. Texto apresentado no evento ALAIC, em Montevidéu, em maio de 2012.

GREIMAS, A. J. A propósito do jogo. Verso \& reverso. São Leopoldo: Unisinos, 1998.

JENKINS, Henry. Cultura da Convergência. São Paulo: Aleph, 2008. 


\section{Fernanda Sagrilo Andres}

Mestra e Doutora pela Universidade Federal de Santa Maria (UFSM). Docente na Universidade Federal do Pampa. Integrante do Grupo de Pesquisa "Comunicação Televisual" - COMTV.

E-mail: fersagrilo@gmail.com

\section{Maria Lília Dias de Castro}

Pós-doutora em Comunicação pela Universidade de Paris 3, Sorbonne Nouvelle. Docente na Universidade Federal de Santa Maria. Coordenadora do Grupo de Pesquisa "Comunicação Televisual" - COMTV.

E-mail:mlilia@terra.com.br

A tese que originou este artigo foi orientada pela Dra. Maria Lília Dias de Castro e defendida em 10/03/2017, na linha Mídia e Estratégias Comunicacionais do Programa de Pós-graduação em Comunicação pertencente à UFSM.

RECEBIDO EM: 10/10/2017

ACEITO EM: 10/10/2017 